\title{
Meningkatkan Harga Diri Pasien Kusta Dengan Terapi Kelompok
}

\author{
Fajar Rinawati ${ }^{1}$, Moh Alimansur ${ }^{2}$ \\ Email: ${ }^{1}$ ukhti_fajr@yahoo.com, ${ }^{2}$ ali.mansur75@yahoo.co.id \\ Dosen Akper Dharma Husada Kediri, \\ Jl. Penanggungan No 41 A Kediri, email: akperdh@gmail.com
}

\begin{abstract}
Leprosy is a chronic infectious disease that can cause disability. East Java is the province where leprosy cases are evident in Indonesia. Negative stigma on people with leprosy can cause serious psychosocial problems, one of them is low self esteem. The purpose of this study was to identify the effects of group therapy toward self esteem of patients with leprosy. The design of this study was quasy-experimental design with one group intervention with total sampling method. The sample of this study ware patients in inpatient care (14 respondents). The results showed that there were significant differences of self esteem between before and after intervention ( $p$-value=0,033). Patients with leprosy need to change their negative perception in order to be able to adapt positively.
\end{abstract}

Keywords: supportive group, self esteem, leprosy

\section{Pendahuluan}

Penyakit kusta atau lepra (leprosy) merupakan penyakit menular kronis yang disebabkan oleh Mycobacterium leprae (Depkes RI, 2006). Gejala yang muncul pada penyakit kusta mulai adanya bercak di kulit, hingga kecacatan (Noto \& Schreuder, 2010).

Stigma yang sudah sangat melekat dengan penyakit kusta membuat pasien maupun lingkungan sekitar (termasuk keluarga) beranggapan negatif terhadap penyakit maupun penderita itu sendiri. Menurut Mead (1934) dan Cooley (1956) dalam Pantalone (2013), stigma atau diskriminasi orang lain akan mengakibatkan persepsi yang negatif pada dirinya dan memunculkan harga diri rendah hingga ketidakinginan untuk merawat diri.

Penyakit kusta merupakan penyakit yang dapat disembuhkan. Pemerintah telah mencanangkan program pengendalian penyakit kusta, antara lain penemuan penderita, diagnosis dan klasifikasi, pengobatan dan pengendalian pengobatan, pencegahan cacat dan perawatan diri, serta rehabilitasi medik (Depkes RI, 2006). Semua program yang digalakkan pemerintah belum menyentuh sisi psikososial pasien kusta, padahal dampak psikososial akibat stigma yang muncul sangat besar.

Dukungan sosial sangat dibutuhkan dalam memberikan terapi yang holistik pada pasien dengan kondisi kronis yang membutuhkan perawatan yang lama (Varcarolis, 2010). Teman dengan kondisi yang sama (komunitas yang sama) dapat membantu pasien berbagi pengalaman, membuat pasien merasa tidak sendiri, merasa diterima, saling mendukung, menurunkan rasa terasing, menurunkan kecemasan, merasa nyaman, dan bisa saling membantu satu sama lain (Townsend, 2009).

Jawa Timur merupakan propinsi dengan jumlah kasus kusta tertinggi di Indonesia. Terdapat dua Rumah Sakit khusus kusta di Jawa Timur yang merupakan Rumah Sakit milik Pemerintah Propinsi, yaitu Rumah Sakit Kusta Kediri dan Rumah Sakit Kusta Sumber Glagah Mojokerto. Rumah Sakit Kusta Kediri masih merupakan Rumah Sakit satusatunya yang hanya melayani pasien khusus kusta sedangkan Rumah Sakit 
Sumber Glagah sudah menerima pasien umum.

Berdasarkan latar belakang di atas maka peneliti tertarik untuk meneliti tentang pengaruh terapi kelompok dalam meningkatkan harga diri pasien kusta di Rumah Sakit Kusta Kediri Jawa Timur.

\section{Metode Penelitian}

Desain dalam penelitian ini menggunakan desain quasi-experiment one group pretest-posttest design yang melihat pengaruh suatu intervensi, yaitu terapi kelompok terhadap harga diri pada pasien kusta. Populasi dalam penelitian ini adalah semua pasien yang di rawat di Ruang Rawat Inap RS Kusta Kediri saat dilakukan penelitian. Metode sampling yang digunakan adalah total sampling dengan beberapa kriteria inklusi. Jadi jumlah sampel yang didapatkan sebanyak 14 responden.

\section{Hasil Penelitian}

Hasil penelitian ini dijabarkan tentang karakteristik responden dan harga diri pasien sebelum dan sesudah terapi.

\section{Tabel 1 Karakteristik Responden}

\begin{tabular}{lcc}
\hline \multicolumn{1}{c}{ Kategori } & Frekuensi & Persentase \\
\hline Jenis Kelamin & & \\
a. Laki-laki & 11 & 78,6 \\
b. Perempuan & 3 & 21,4 \\
\hline Pendidikan: & & \\
a. Tidak Sekolah & 2 & 14,3 \\
b. SD & 9 & 64,3 \\
c. SMP & 2 & 14,3 \\
d. Buruh & 1 & 7,1 \\
\hline Pekerjaan: & & \\
a. Tidak bekerja & 5 & 35,7 \\
b. Swasta & 3 & 21,4 \\
c. Wiraswasta & 3 & 21,4 \\
d. Buruh & 3 & 21,4 \\
\hline Status Perkawinan: & & \\
a. Belum menikah & 4 & 28,6 \\
b. Menikah & 5 & 35,7 \\
c. Janda/Duda & 5 & 35,7 \\
\hline
\end{tabular}

Selain itu karakteristik responden juga dilihat berdasarkan lama sakit. Ratarata usia responden adalah 46,86 dan lama sakit responden adalah 105,21 bulan.
Tabel 2 Perbedaan Harga Diri Sebelum dan Sesudah Terapi $(n=14)$

\begin{tabular}{lcc}
\hline \multicolumn{1}{c}{ Pengukuran } & Mean & p-value \\
\hline Sebelum terapi & 30,79 & \multirow{2}{*}{0,033} \\
Sesudah terapi & 24,57 & \\
\hline
\end{tabular}

Tabel 2 menunjukkan bahwa ada penurunan skor harga diri antara sebelum dan sesudah terapi. Ini berarti bahwa ada peningkatan harga diri responden setelah diberikan terapi. Analisis beda rata-rata skor harga diri antara sebelum dan sesudah terapi menggunakan uji t-test berpasangan menghasilkan nilai probabilitas sebesar 0,033 ( $\mathrm{p}$ value < 0,05). Hasil ini menunjukkan adanya perbedaan yang signifikan antara skor harga diri sebelum dan sesudah terapi.

\section{Pembahasan}

\section{Analisa Karakteristik Responden}

Usia yang paling banyak pada penelitian ini adalah usia dewasa menengah (40-65 tahun). Usia dewasa menengah merupakan usia kemandirian dalam hidup, mencapai karir yang memuaskan, dan mencapai tanggung jawab penuh (Kozier, 2011). Tugas-tugas perkembangan ini merupakan suatu ideal diri yang menuntut pasien mampu mencapainya, sehingga pasien dapat mengalami stres emosional. Seperti yang diungkapkan Depkes (2006) bahwa reaksi kusta juga ditimbulkan karena adanya stres emosional.

Hasil penelitian yang telah dilakukan juga menunjukkan bahwa sebagian besar responden mempunyai status tidak kawin, yaitu belum menikah $(28,6 \%)$ dan janda/duda $(35,7 \%)$. Status tidak kawin menjelaskan bahwa ia tidak bersama dengan istri atau suaminya bahkan mungkin pula tidak dengan keluarganya. Padahal keluarga sangat dibutuhkan dalam merawat pasien. Friedman (2010) mengungkapkan bahwa salah satu fungsi keluarga adalah fungsi perawatan. Seperti penelitian Roosihermiatie (2006) mengungkapkan bahwa status tidak 
kawin, mempunyai hubungan positif yang signifikan terhadap cacat.

Hasil penelitian yang telah dilakukan juga menunjukkan bahwa rata-rata lama sakit adalah 105,21 bulan atau 8,8 tahun. Selama ini banyak pasien yang mengeluhkan kenapa pengobatan sudah selesai namun tidak ujung sembuh. Ini merupakan waktu yang cukup lama dalam suatu proses penyakit. Hal ini bisa disebabkan karena adanya resistensi obat kusta pada pasien. Adanya dosis yang tepat dan keteraturan minum obat merupakan hal yang harus diperhatikan oleh pasien maupun keluarga selaku pengawas minum obat. Banyak faktor yang dapat menyebabkan pasien tidak teratur minum obat, misalnya pendidikan yang rendah. Pasien menganggap bahwa ketika sudah minum obat dan tanda gejala sudah hilang, pasien menganggap penyakitnya sudah sembuh. Padahal pengobatan harus tuntas untuk mematikan kuman kusta. Seperti penelitian Erawatyningsih dan Heru (2012) menunjukkan bahwa pendidikan merupakan faktor yang paling dominan dalam mempengaruhi pengobatan. Selain itu dukungan keluarga juga mempengaruhi kepatuhan minum obat pasien, karena keluarga merupakan orang yang tinggal serumah dan dekat dengan pasien, sehingga keluarga dapat mengawasi pasien untuk minum obat. Seperti penelitian (Hutapea, 2009) bahwa dukungan keluarga berhubungan terhadap kepatuhan pasien dalam minum obat.

\section{Analisa Harga Diri}

Penyakit kusta merupakan penyakit infeksi kronis yang dapat menimbulkan kecacatan (Noto \& Schreuder, 2010). Berdasarkan pemeriksaan fisik yang dilakukan saat penelitian, semua responden $(100 \%)$ telah menunjukkan gejala fisik yang jelas akibat penyakit kusta, yaitu 3 orang menunjukkan gejala bercak kemerahan dan pembengkakan pada kulit dan sisanya (11 orang) mengalami kecacatan, mulai dari tangan kiting, kaki semper, luka pada tangan dan kaki, bahkan sampai amputasi.

Dampak yang ditimbulkan akibat penyakit kusta bukan hanya fisik saja, namun juga masalah psikososial (Pantalone, 2013). Selain masalah fisik dan psikososial, juga muncul masalah ekonomi, budaya, spiritual dan sosial. Hampir semua pasien mengeluhkan masalah ekonomi, antara lain tidak bisa bekerja lagi, jualan tapi tidak laku, sudah tidak kuat bekerja keras karena akan menambah parah penyakitnya. Masalah budaya yang muncul antara lain tidak lagi disegani lagi. Masalah spiritual yang muncul antara lain pasien hanya bisa pasrah dan berdo'a menerima sakitnya. Masalah sosial yang muncul antara lain dijauhi oleh keluarga dan tetangga sehingga membuat pasien mengurung diri (mengalami isolasi sosial).

Suatu penyakit merupakan salah satu stresor pada diri manusia (Stuart, 2013). Penyakit kusta juga merupakan suatu stresor yang dapat menimbulkan masalah fisik dan dapat menyebabkan masalah psikologis, sosial, ekonomi, budaya dan spiritual atau sebaliknya. Kozier (2011) mengungkapkan bahwa manusia adalah makhluk yang holistik, yaitu mempunyai kebutuhan bio-psiko-sosio dan spiritual yang harus diperhatikan semuanya. Oleh karena itu asuhan keperawatan pada pasien harus dilakukan secara menyeluruh, bukan hanya fisik saja.

Harga diri rendah yang dialami oleh penderita kusta semakin diperberat dengan adanya stigma negatif dan perlakuan diskriminatif. Banyak penelitian yang mengembangkan terapi kelompok akibat adanya stigma negatif (Pantalone, 2013).

\section{Analisa Perbedaan Harga Diri Sebelum dan Sesudah Terapi}

Berdasarkan hasil penelitian didapatkan bahwa selisih antara harga diri sebelum dan sesudah terapi adalah 6,22. Selisih ini bisa ditingkatkan dengan meningkatkan kualitas dari pelaksanaan terapi, antara lain jumlah sesi ataupun 
pertemuan yang ditambah, jumlah waktu atau lama pertemuan ditambah, dan jumlah kehadiran. Pada pelaksanaan sesi 1 tentang identifikasi masalah, jumlah pertemuan bisa ditambahkan. Kegiatan pada sesi 1 ini dapat menggali lebih dalam masalah-masalah yang timbul akibat penyakit kusta. Selain pasien bisa mengungkapkan masalah yang dialami, juga melatih pasien berbicara di depan kelompok. Hal ini yang dapat memunculkan kepercayaan diri pasien. Begitu pula pada sesi-sesi berikutnya, waktu pertemuan bisa ditambahkan untuk melatih pasien dalam bersosialisasi, berbagi perasaan, berbagi pengalaman, belajar mengungkapkan permasalahan dan cara penyelesaianannya, serta dapat memberikan kesempatan pada pasien lain untuk bergantian menjadi pemimpin.

Penyakit kusta yang menimbulkan stigma negatif dan diskriminasi membutuhkan suatu penyelesaian, terutama mengurangi stigma di masyarakat. Masih banyak masyarakat yang mempunyai persepsi negatif tentang kusta. Seperti penelitian Rachman (2012) menunjukkan bahwa persepsi masyarakat tentang penyakit kusta adalah pentakit keturunan dan kutukan, penyebabnya karena lingkungan yang kotor, bakteri dan guna-guna, dan masyarakat masih takut berinteraksi dengan penderita. Persepsi negatif yang sangat melekat ini akan menimbulkan resistensi di masyarakat. Oleh karena itu, harus dicari solusi atau metode yang tepat untuk menyelesaikannya.

Terapi kelompok merupakan salah satu metode yang dapat meningkatkan harga diri pasien kusta. Diharapkan dengan meningkatnya harga diri, akan membuat pasien lebih percaya diri dalam menghadapi masyarakat, namun jika tidak ada kerjasama yang baik antara semua pihak, masyarakat akan terus berfikir negatif tentang kusta dan ini yang akan membuat pasien mengalami penurunan harga diri kembali. Jadi selain menyiapkan pasien di Rumah Sakit dalam meningkatkan harga diri, masyarakat tempat ia akan kembali juga harus disiapkan untuk menerima pasien, sehingga masyarakat akan memperlakukan mantan pasien kusta seperti yang lain (tidak diskriminatif).

\section{KESIMPULAN \\ Simpulan}

Karakteristik pasien kusta di Rumah Sakit Kusta Kediri berdasarkan jenis kelamin terbanyak adalah laki-laki, usia terbanyak adalah dewasa menengah, lebih dari setengahnya berpendidikan SD, kurang dari setengah tidak bekerja, lebih dari setengah bersattus tidak kawin, dan rata-rata lama sakit lebih dari 5 tahun. Terjadi penurunan skor harga diri antara sebelum dan sesudah terapi atau ada peningkatan harga diri sesudah dilakukan terapi dan secara signifikan terapi kelompok berpengaruh terhadap harga diri pasien kusta.

\section{Saran}

Saran bagi keilmuan, terapi kelompok merupakan salah satu terapi yang tepat digunakan dalam meningkatkan harga diri pada pasien kusta, sehingga penyempurnaan pelaksanaan terapi perlu dilakukan, antara lain dengan menambah jumlah pertemuan pada masing-masing sesi, dan menambah jumlah sampel dalam penelitian, serta membuat kelompok yang lebih homogen.

Saran bagi pasien diharapkan mampu mengimplementasikan apa-apa yang sudah didapatkan selama terapi. Pasien dapat lebih aktif untuk menanyakan atau berkonsultasi ke petugas kesehatan terkait penyakit ataupun masalah yang ditimbulkan akibat kusta. Keluarga diharapkan mampu menjadi support system yang baik bagi pasien, bukan hanya dari segi material, namun juga memberikan dukungan psikologis pada pasien. Saran bagi perawat diharapkan mampu melaksanakan asuhan keperawatan secara komprehensif, bukan hanya berfokus pada masalah fisik saja, 
namun juga masalah psikososial. Saran bagi Dinas Kesehatan diharapkan lebih meningkatkan lagi program kusta dengan memberikan penyuluhan kesehatan pada pasien kusta, keluarga dan masyarakat sekitar tempat tinggal penderita kusta. Penyuluhan kesehatan juga bisa diperuntukkan bagi umum, misalnya melalui media elektronik atau media cetak. Selain itu Dinas Kesehatan juga dapat membuat program konsultasi (baik langsung maupun online) yang bisa diakses oleh masyarakat luas, baik penderita kusta, keluarga atau masyarakat terkait adanya keluhan-keluhan atau masalah tentang kusta khususnya. Saran bagi Dinas Sosial diharapkan dapat menjalin hubungan baik dengan Rumah Sakit Kusta dan Dinas Kesehatan untuk meningkatkan kualitas hidup penderita kusta, antara lain adanya latihan kerja atau penyediaan lapangan pekerjaan bagi penderita kusta. Saran bagi peneliti selanjutnya perlu dilakukan penelitian yang bersifat kualitatif yang dapat menggali lebih jauh aspek-aspek yang terkait penyakit kusta, antara lain persepsi penderita, keluarga dan masyarakat tentang kusta. Selain itu juga dapat dilakukan penelitian terkait tentang strategi koping yang dilakukan dalam menghadapi penyakit kusta.

\section{Daftar Pustaka}

Departemen Kesehatan Republik Indonesia. (2006). (RI, 2006) (Cetakan ke-18). Jakarta, Indonesia: Author.

Erawatyningsih, P., \& Heru Subekti, E. (2012). Faktor-faktor yang Mempengaruhi Ketidakpatuhan Berobat pada Penderita Tuberkulosis Paru, Jurnal Berita Kedokteran Masyarakat (BKM), 25 (3), 117

Friedman, M.M. (2010). Buku Ajar Keperawatan Keluarga. Riset, Teori dan Praktik. Jakarta: EGC.
Hutapea, T. (2009). Pengaruh Dukungan Keluarga Terhadap Kepatuhan Minum Obat Anti Tuberkulosis. Jurnal Respirologi Indonesia (serial on the internet), 29 (2).

Kozier, B. et al. (2011). Buku Ajar Fundamental Keperawatan, Konsep, Proses \& Praktik. Jakarta: EGC.

Noto, S. \& Schreuder, P.A.M. (2010). Cinical Leprosy. Genoa

Pantalone, M. (2013). Alcohol-related problems and self-help groups: The situational construction of self-image. Italian Sociological Review, 3(2), 7183. Retrieved from http://search.proquest.com/docview/1 $\underline{443261095 \text { ? accountid }=17242}$

Rachman, H.W.A. (2010). Pola Pencarian Penderita Penyakit Kusta di Kotamadya Makasar.

Roosihermiatie, B. dkk. (2006). Faktor Sosioekonomi dan Kegiatan Tertentu yang Berhubungan dengan Derajat Kecacatan dan Kadar Immunoglobulin Penderita Kusta Bebas Obat di Liponsus Benowo Surabaya. Buletin Penelitian Kesehatan (Volume 34), 72-82.

Stuart, G.W. (2013). Principles and Practice of Psychiatric Nursing. $10^{\text {th }}$ Ed. Canada: Evolve.

Townsend, M.C. (2009). Psychiatric Mental Health Nursing, Concepts of Care in Evidence-Based Practice. $6^{\text {th }}$ Ed. Philadelphia: Davis Plus.

Varcarolis, E.M. \& Halter, M.J. (2010). Psychiatric Mental Health Nursing, A Clinical Approach. $6^{\text {th }}$ Ed. Canada: Elsevier. 